\title{
Posthumanism and Its Animal Voices in Literature
}

Anna Barcz 
Anna Barcz

\section{Posthumanism and Its Animal Voices in Literature}

DOI: 10.18318/td.2015.en.1.15

$\mathbf{W}$ here do we come from? Who are we? Where are we heading? Gauguin's garden - full of animals, rootstock and half-naked figures - shows the ephemeral condition of the human being, or in a more general sense, the condition of an exotic creature whose life fills the space between birth and death. Multiple human and non-human forms provoke questions about a given community, certain "us" but is this community defined solely through that which is human?

In Bruno Latour, Donna Haraway or Ewa Domańska's texts, the question about posthumanism concerns the world shared with other nonhuman beings or even things having causative functions. "What is posthumanism?" is a question which is also asked in his book by Cary Wolfe", a well-known theoretician of culture. His response and
Anna Barcz - PhD, lecturer in the Department of English Studies in the ATH in BielskoBiała, collaborator of the IBL PAN. Her research interests include: ecocriticism, cultural research of animals. Co-editor of Zwierzęta i ich ludzie (2015). Contact: anna. barcz@gmail.com

1 Cary Wolfe, What is Posthumanism? (Minneapolis: University of Minnesota Press, 2010). The issue 1-2 of Teksty Drugie (2013) contains a chapter from this book: Animal studies, dyscyplinarność i post(humanizm) in Karolina Krasuska's translation. Referring to it, however, I will be forced to point to the original publication. It is worth noting that Wolfe is the author of two more books which firmly establish his approach towards posthumanism: Critical environments (1998) and Animal rites (2003) and the editor of the series Posthumanities in the University of Minnesota Press.

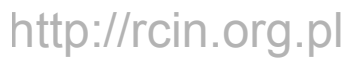


the way of thinking he suggests seem - similarly to other theoreticians working in this area - to challenge traditional, fundamental assumptions of the humanities which place the human at the top of the hierarchy, promote anthropocentrism and assume the identity built upon the belief in one's ability to create knowledge about the world. As a matter of fact, Wolfe's posthumanism differs from the rest of "post" theories. His reformatory thought is exceptionally dynamic owing to a new sensitivity mainly focused on the presence of animals in the environment, culture, history - both before and after humanism, but also on the relations between animals and people. He formulates it even more explicitly by claiming that interest in animals needs to be confronted with posthumanism not only from the perspective of the subject of cognition, but also in terms of the method of cognition ${ }^{2}$. The human, modern and emancipated subject of cognition stops being an interesting point of reference.

\section{Why Wolfe's Posthumanism?}

As a rule, new terms do not inspire trust. Some people believe that posthumanism resembles yet another "turn" in the humanities, just like many other ones which enthusiastically reach out to interdisciplinary nooks and crannies, edges of oblivion but not yet sufficiently explored in the discourse so that an illusion of cultural progress could be maintained, while in fact are subject to the mechanism of the market focused on unique, innovative interpretations. However, this judgement would not be fair because posthumanism aims at strengthening the status of theory in contemporary knowledge of which the humanities are an integral part, and at a more understanding, universalising but not universal language. Reading Wolfe inevitably brings to mind associations with the return of the great theory. It is perhaps a legitimate connotation, although it would have been the return of a theory formulated without sentiment, cautiously, with awareness of the outcome of earlier, totalising ideologies based on rationalistic foundations. Equipped with instruments typical of the 2oth-century criticism, Wolfe analyses philosophy, literature, film, music, art or even architecture. He wants to popularise a certain concept by embedding it in the knowledge necessary to survive - despite appearances, not utopian but pragmatic and penetrating the very essence of thought ("the nature of thought itself must change if it is to be posthumanist" 3 ) - and not in the problem of the subject cultivated by humanists. According to this

\footnotetext{
2 Wolfe, What is Posthumanism?, 99.

3 Ibid., XVI.
} 
ambitious project, the "post" humanities are able to go back to both the scientific and political debate as it generated adequate critical and interpretational instruments not only to help empirical sciences provide knowledge but also to protest when they violate the well-being of multispecies ecosystems and sentient individuals ${ }^{4}$. Wolfe's project values the culture-forming role of beings other than humans, usually not existing in the world as subjects but participating in something that could be described as the community of life.

In the introduction to his book, Wolfe discusses Foucault's belief about the decline of man expressed in The Order of Things (Les mots et les choses). The key principle of the posthumanities - that perhaps we do not deal with human beings anymore but with their remains - stirs up most controversies and misunderstandings. At first Wolfe seems to translate it to such a model of thinking about man which cuts him off from what is nonhuman, animal, natural. Agamben does something similar in his book Open. Human and Animal (L'aperto. L'uomo e l'animale) employing the notion of the anthropological machine ${ }^{5}$. Wolfe also perceives the genesis of posthumanism in the development of cybernetics and the systems theory. These inventions pushed homo sapiens down from the position of a privileged being knowing how to apply meanings and convey information, and having unique cognitive skills. Still, the scholar distances himself from the cyborgian faction of posthumanism - sometimes called transhumanism - because, as he underlines, it is created in the spirit of the Enlightenment rationalism with much emphasis on the transformation of man into superman, a certain stage on the linear path to perfection as in Condorcet's or Kant's philosophy ${ }^{6}$. Wolfe's view is distinctive for avoiding futurology, diagnosing the state of the humanities,

4 To posthumanism, prone to empathy towards animals, it is vital that all vertebrates qualify as critters who are able to experience or are aware of experiencing - cf. e.g. Andrzej Elżanowski, The moral career of vertebrate values in Evolutionary ethics, ed. Matthew $\mathrm{H}$. Nitecki, Doris V. Nitecki (New York: State University of New York Press, 1993). This knowledge mainly derives from natural scientists' findings, since animals have long been the subject of biological, zoological or ethological research. Nonetheless, basic behavioral transformations in people's treatment of animals, raising the question of their subjectivity, decreasing their pain and stress as well as legal adjustments have been elaborated in the area of the humanities and social science which denoted cultural changes.

5 Giorgio Agamben, L'aperto. L'uomo e l'animale, 2002 - chapter 9 in particular. Fragments of other chapters which mention the anthropological machine were translated by Paweł Mościcki and published in Krytyka Polityczna 15 (2008): 124-138.

6 Jean Antoine Nicolas de Condorcet, Szkic obrazu postępu ducha ludzkiego poprzez dzieje, trans. Ewa Hartleb, Jan Strzelecki(Warszawa: PWN, 1957). Immanuel Kant, Co to jest Oświecenie?, in: Przypuszczalny początek ludzkiej historii, trans. Adam Landman (Toruń: Comer, 1995). 
for the evolutionary approach to language, acknowledgment of the biological origins of man and non-hierarchical treatment of humans and animals. $\mathrm{He}$ points to earlier concepts formulated by the eighteenth-century thinker La Mettrie, who - independently of the rationalist idea of progress which being developed already at that time - wrote in his L'Homme Machine: A Study in the Origins of an Idea (L'homme-machine):

The transition from animals to man is not violent, as true philosophers will admit. What was man before the invention of words and the knowledge of language? An animal of his own species with much less instinct than the others. In those days, he did not consider himself king over the other animals, nor was he distinguished from the ape, and from the rest, except as the ape itself differs from the other animals, i.e., by a more intelligent face ${ }^{7}$.

Already before Darwin, this doctor and philosopher stigmatised vanity and belief in the superiority of human nature considered as unjustified on account of biological resemblances between the two species: sensitivity to pain, suffering, the ability to feel pleasure. For that reason he wrote that both man and animal co-create the organic and sentient machine. By that he wanted to underline how much all creatures have in common when they express joy, pain or produce psychologically more complex reactions ${ }^{8}$. And what is most important, he claimed that man is like a mole - more limited in his scientific research than he/she thinks in the moments when he/she haughtily marks the borders of knowledge to what has no borders, negates animals' intelligence without which they would not be able to perform their everyday activities and despite his/her resemblance to them, he/she keeps treating them badly9.

Wolfe must not be accused of being insensitive to the culture-forming function of memory in the contemporary humanities. He repeatedly stresses that the posthumanities do not reject but rather accept their historical dimension - contrary to e.g. Katherine Hayles with whom he often disputes in What is Posthumanism? ?10. Hayles, whose book How we Became Posthuman was published earlier than Wolfe's work, opts for separating informational reality

7 Julien Offray de La Mettrie, Man a Machine, trans. Gertrude Carman Bussey (Chicago: The Open Court Publishing Co., 1912), https://archive.org/details/manmachineoolame .

8 Ibid.

9 Ibid.

10 Wolfe, What is Posthumanism?, e.g. 120-122. 
from bodily reality. According to her concept, following the creation of advanced computer "electronic prostheses", the subject functions more fully in virtual reality which contributes to the failure of the liberally comprehended individuality. Hayles mainly concentrates on the development of technologies (Hans Moravec's robotics) and speculations over the consciousness separated from the body in science fiction literature (in Philip Dick's stories, among others) ${ }^{11}$.

Wolfe's posthumanism emerges from the reflection re-evaluated through the experience of the human tragedies of the last century. The scholar deliberately follows this approach without exposing his method. It is not surprising, therefore, that his theory seems as if it aspired to alter ethical attitudes. Wolfe does not reject the recurring reflection concerning memory, trauma and sacrifice; he does not asses which of these categories are more or less critical to the human condition hic et nunc in the traditional humanities. Instead, he tries to show or remind us with subtlety that these notions are not reserved for man only. Hence his posthumanism is somehow the result of the remorse accelerated by inhuman crimes revealing evil in mankind; it is the sign of katharsis, atonement stemming from the natural need of adjusting to the changeable reality. This inhuman and sinister dimension of man also concerns the world which humans share with nonhuman animals. It is about a new alternative for the rationally legitimised rule of man over other creatures - an alternative expressed in a different, less emotional language than in the Dialectic of Enlightenment. Such well-grounded critique of humanism appears to be most accurate from the ethical and political point of view because the culture-forming role of humanism in maintaining the anthropocentric perspective "validates whatever serves human interests and, as a consequence, projectively situates other animals, or animality in general (including the animal in the human being), in the position of bare life, raw material, or scapegoated victims"12. Through posthumanism, the meaning of what is human dissolves in favour of the ramification of the human in the nonhuman language understood here as an evolutionary construct reflecting pre- or postanthropocentric recesses - free of reflection and introspection of the critical subject in humanism ${ }^{\mathbf{1 3}}$. Man, as underlined by Wolfe, evolved from various nonhuman and unhumanizable forms, hence the component of

11 Katherine N. Hayles, How We Became Posthuman: Virtual Bodies in Cybernetics, Literature, and Informatics (Chicago-London: University of Chicago Press, 1999). University Press, 2009), 151. 
nonhuman otherness is permanently present in him/her. The posthumanist approach, therefore, exhibits a new genetic perspective - first taken up by Jacques Derrida in his L'Animal que donc je suis and La bete et le souverain, then continued by Wolfe - which raises questions about nonhuman or prehuman ancestors of man understood both literally and metaphorically, existentially. It is about such aspects of man and such relations between humans and animals which grew into culture and history, creating new constellations, new comprehension of existence in the world; and about such thinking which is now heard through numerous voices not at all reserved for humans - this is clearly visible in literature and animal narrations. Posthumanism admits other than human voices if they are constitutive to man who is in a stable relationship with them. Even the voice itself - always belonging to an individual - is not human by nature. According to Wolfe, this approach opposes the domination of the most human of all senses: sight, which may demonstrate the loss of the world's vision based on its visual side ${ }^{14}$.

Wolfe does not primarily interpret the prefix "post" as something that is "after" despite its meaning in Latin: "coming after". The critique of humanism as a radical anthropological dogma which - in order to function with stability - requires extraction of human nature in the form that is immaterial, incorporeal and separate from nature, points to another Latin meaning of "post", suggesting that beyond and be side humanism there exist alternatives. We are not the only ones to use symbolic language ${ }^{15}$. We are simply at such a stage of evolution when we have made language not only an effective instrument of power and ideology which sanctions human domination over other species but also an exceptional tool of art and understanding of the world around us. This duality is present in Wolfe's posthumanism but it does not prevent him from challenging the key normative idea of humanism, i.e. human

14 Ibid., 169-202 (the chapter in which Wolfe interprets the function of the voice in the film Dancer in the Dark).

$15 \mathrm{Cf}$. research on teaching animals the language which gave astonishing effects in the case of: Rico, a Border Collie about which Cary Wolfe writes in Thinking other-wise. Cognitive science, deconstruction and the (non) speaking (non) human subject in Animal subjects: an ethical reader in a posthuman world, ed. Jodey Castricano, (Waterloo: Wilfrid Laurier University Press, 2008), 127-128; Kanzi, a bonobo, a female gorilla Koko, the orangutan Chantek and common bottlenose dolphins: Phoenix and Akeakamai described by David DeGrazia in On the Question of Personhood beyond Homo sapiens in In Defense of Animals, ed. Peter Singer (Oxford: Blackwell Publishing, 2006), 48. Accessed July 5, 2015, http://isites.harvard.edu/fs/docs/icb.topic983317. files/Readings\%20October\%2026/AgainstZoos_DaleJamieson.pdf. Linguistic competences demonstrated by these animals are so high that researchers do not hesitate to admit that they actually use a symbolic language. They are also exceptional cases within their species. If they had human vocal cords, they would probably speak to us with their own voice. 
subjectivity which usually reinforces discrimination of nonhuman animals and disabled humans. At the same time, this leads him neither to naturalisation of consciousness - close to the assumptions of modern cognitivism and philosophy of mind - nor to transhumanism proposed by Hayles.

In any case, being critical is not the only element of posthumanism important because it leads to a pursuit of new forms of expression and literary strategies which take into account and affirm other subjects of life; strategies shedding new light on literature. This proposition is also different from the ones put forward by Hayles, Haraway or Latour. In How we Became Posthuman, Hayles privileges the informational dimension of the posthuman over the material one which leads to the futurological reflection regarding the impact of cybernetics on the immaterialised human existence and this approach is often confused with transhumanism. Haraway - certainly closer in her thought to Wolfe - discloses a palpable evolution of views in her book When Species Meet: from the cyborg to the reflection on inter-species encounters. First, she rejects humanism due to its nonemancipatory character (the cyborg demonstrated the desintegration of a certain arrangement of the body, sex and social class) to indicate subsequently the absence or even inabsorbability of the idea of love and partnership between biological species - which she experiences herself in her relations with dogs ${ }^{\mathbf{1 6}}$. Latour, on the other hand, focuses on the narration of the twilight of modernism, the criticism of the ideologisation of nature and the decline of the idea of representation in developed democratic human societies; criticism which encourages opening of the heretofore anthropocentric society to other species of both plants and animals. Transformation of the human political system will locate man within the framework of a new collective (not a society any more) in which humans and nonhumans will be capable of creating "associations", i.e. newly interpreted communities organised around environmental interests also understood in terms of non-anthropocentric goals ${ }^{\mathbf{1 7}}$. This also explains the need to modify the language, to re-define the terms which will level up the political, the social and the natural. Obviously, these are not all propositions of changes that radically reject what traditionally belongs to humanism, i.e. what is human.

16 Donna J. Haraway, When Species Meet (Minneapolis-London: University of Minnesota Press, 2008); cf. also Joanna Żylińska's article Bioetyka inaczej, czyli o tym jak współżyć z maszynami, ludźmi i innymi zwierzętami, to a large extent being a commentary to Haraway's ideas expressed in the above-mentioned book; the Polish translation of the article is reprinted in Teksty Drugie 1-2 (2013).

17 Among others, Polityka natury. Nauki wkraczaja do demokracji, trans. Agata Czarnacka; introduction: Maciej Gdula (Warszawa: Wydawnictwo Krytyki Politycznej, 2009). 
Other authors who work on the theory of evolution - such as Elizabeth Grosz - also share the conclusion that man only constitutes a certain stage, unfinished and unready, in a lengthy process of changes ${ }^{18}$. There also scholars who use biographical narration to show the act of passing from bios to zoe which means that the category of life eliminates the subjective "I" from the centre of reflection in favour of the relation between bodies, species and machines ${ }^{19}$.

All those proposals, diversely privileging the posthumanist reflection, provide Wolfe with a significant context but are not sufficient to explain the need to claim posthumanism as an independent direction. Wolfe himself accentuates the variety of subjects of life - including the nonhuman ones - however, he also points out that the act of placing man in the world of technology plays a different role than his biocultural heritage and the consequences of the humanistically defined world ${ }^{20}$. Technologies benefit the exchange of information but what makes machines different from animals and humans is their inability to participate in the reality of organic life in which the act of hurting a living creature, although isolated, escapes the possibility or ability of articulation. This wound - often bloody, evoking cruelty and control of one over another - will separate the living from the merely functioning. And, even though life itself is too broad of a problem to research, posthumanism represented by Wolfe is about what is alive, feels and increasingly shares our experiences, both constitutive for man and the ones beyond him/her but staying in relation with him/her. That is the reason why mediation of animals is so important in this theory - mediation associated with development of animal studies which, to Wolfe, are meaningful methodologically as they reform the humanities and practices within the literary studies ${ }^{21}$.

18 Elizabeth Grosz, The Nick of Time. Politics, Evolution and the Untimely (Durham, NC: Duke UniversityPress, 2004); ead. Becoming Undone. Darwinian Reflections on Life, Politics and Art (Durham,NC: Duke University Press, 2011).

20 Here the point is neither about the concept of man perceived as a defective being for whom technologies are the necessary supplement. Wolfe ceaselessly emphasises the impossible to maintain normative category of an independent human subject. inspired also by Wolfe but above all by the development of animal studies abroad. At the same time, she underlined that the greatest obstacle on the way to carry out this undertaking in Poland is the lack of seriousness in treating animals as subjects of research (beside the empirical studies) - cf. Monika Bakke, "Studia nad zwierzętami: od aktywizmu do akademii i z powrotem?", Teksty Drugie 3 (2011): 193-204. 


\section{Bridge to Reality}

In opposition to literary Darwinism desiring to "rescue" the literary studies from the "catastrophe" of poststructuralism, particularly by means of Joseph

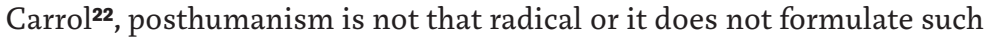
radical objectives. This is not to say that the theory of evolution and Darwin's thought did not influence the forming of posthumanism. Among the important consequences of Darwinism which are significant to the theory discussed in this article, it is worth to mention the role of empathy, the raising of questions about ethics in relations with animals, extending the meaning of moral harm onto animals, using critical anthropomorphism in presenting them and the entire stream of the achievements of empirical studies which affected not only the change of the animals' status but also practices of analysing and reading of texts of culture in which they appear. Posthumanism is the only contemporary intellectual direction to suggest that the previous vision of the Euro-American humanities with the central category of the human subject does not offer any alternative to nonhuman areas being under the hegemony of the human kind. By attacking anthropocentrism and species chauvinism, it mirrors the avant-garde intuition in thinking about the relation between man and the rest of the world, especially nature. What is questioned here is not only the line separating us from the nonhuman world but the separatedness itself, the emancipation of the human subject from other culturally unrecognizable subjectivities. And the assumptions concerning the ontological liquidity or the mystical identification and equalisation of all beings are unnecessary. It is man - multidimensional, relational in his/her existence in the world which makes him/her unexceptional because he/she experiences finiteness in its physical, material and mortal aspect - who still remains a model of others' cultural inclusion due to his/her developed skills in managing instruments of expression, also the finite ones, whose functionality and otherness is so strongly underlined by Wolfe. The technological and nonhuman nature of the language, always being in a certain relation with the world, less often undergoes a reflection, while it turns out that notions, constructs, narratives and any linguistic entities that we perceive as "ours" are actually not ours which is also a kind of experience ${ }^{23}$. The feeling of strangeness in language, culture or nature entails the feeling of constant mediation. The animal's appearance brings back the ability to experience reality and enables the reconstruction of our bonds with the outside world making it culturally significant. Thanks to ex te r n a l

Cf. Krzysztof Kłosiński, "Literaturoznawczy darwnizm", Teksty Drugie 3 (2011), 33-51.

Wolfe, What is Posthumanism?, 89 (in the context of the other subjectivity) and 119. 
instruments, animals seem the closest, the most special connectors, mediators between people and the impersonal world of nature - and their anthropomorphisation also serves this purpose $\mathrm{e}^{24}$. Anthropomorphisation, however, appears differently in the empirical discourse than in the literary one. Literature or art may have effects on the aesthetic level; it can still be a specific road to cognition because what cannot be gleaned with the help of discursive arguments, penetrates through imagination via an as if separate, nontheoretical channel.

So far, the goal of the reflection about animals in culture has been to discover something noteworthy about human nature. Posthumanism repudiates such an approach. The animal ceases to be a mirror of human desires, passions, anomalies; a carrier of permanent features of the moralistic character - like in fairy tales; it does not symbolise the world of humanist values any more mainly because it becomes a specific, individually characterised hero, a persona hiding a real creature behind the mask. In the posthumanist perspective, literature tries to abandon the notion of a person limited to a human being and expand research to other subjects of communication, while looking in people for something that allows us to receive information, signals, and stimuli from other nonhumans or that is an obstacle in communication with nonhuman individuals ${ }^{25}$. Simultaneously, it is implied that animals are much more strongly present in the reflection than in everyday life as modernity contributed to the elimination of the representation of the wild and the uncivilised from the human domain which, consequently, enabled the development of various technologies ${ }^{26}$. In this respect, the return of animals is also the return of the Other who arouses interest and enforces being referenced to but cannot be completely familiarised. Thus, numerous methods of anthropomorphisation in literature - when people and the language of their experiences become an intellectual model for animals - aim at not only bringing animals back to thinking (about them and with them) but also letting us understand them better, grasp what they feel and experience, see whether and how to come into contact with them. All this evokes our reflection which unveils another life - perhaps similar to ours, though not embedded in the complex system of notions. Questions such as "what is it like to be

24 It is possible that the animal resembles a medium in Régis Debray's broad understanding presented in his Introduction à la médiologie (2000), and although it is not there literally, it may participate in conveying culturally significant information.

25 Wolfe, What is Posthumanism?, 115-118.

26 Akira Mizuta Lippit, Electric Animal: Toward a Rhetoric of Wildlife (Minneapolis: University of Minnesota Press, 2000), 2-3. 
a bat"27 hitherto considered as nonsense and reduced to absurd, especially in the field of analytical philosophy and its thriving branch - philosophy of mind - particularly when they are comprehended solely from the zoomorphic point of view (what is it like for a bat to be a bat or whether a human can have a neurophysiological structure of this mammal ${ }^{\mathbf{2 8}}$ ), have a certain cognitive value, if we take into consideration the language of comparative psychology of animals and the possibility of reconstructing conscious, but not subjective, experiences of other forms of life ${ }^{29}$.

The majority of authors agree that anthropomorphism has a critical and sentimental tradition but thanks to the development of scientific research on the cognitive processes animals and the increasing awareness related with environmental ethics, anthropomorphisation began to be the expression of the need to understand and predict the behaviour of other animals. It also reflects the biological conditioning of a human being and the actual similarities between human and non-human animals. Natural sciences interpret the evolutionary continuity between people and other animals their own way but literature - which is devoid of such ambitions - considerably adds to the popularisation of their proper understanding, contributing to cultural changes in human-animal relations which inevitably go side by side with scientific diagnoses. This is, however, neither about comparing the humanities and empirical studies nor about the adequacy of rising "the question of animals" in the interdisciplinary perspective but about a response to what new and unique qualities may be introduced to this issue by a given discipline. This is why Wolfe states that, in this case, what is more accurate is transdisciplinarity understood as filtering the reflection through diverse discourses as well as deepening and a more acute analysis of issues that are common to all of them ${ }^{30}$.

\section{The Functions of Animal Narratives}

Literature provides evidence that, contrary to the biological taxonomy, animals do not appear in the form of sponges, i.e. the first organisms belonging

27 Thomas Nagel, "What is It Like to Be a Bat?", Philosophical Review 83 (1974), accessed July 5 , 2015, http://faculty.arts.ubc.ca/maydede/mind/Nagel_Whatisitliketobeabat.pdf, 435-450.

28 Ibid.

29 Cf. Lorraine Daston, Intelligences: Angelic, Animal, Human in Thinking with Animals: New Perspectives on Animals, ed. Lorraine Daston, Gregg Mitman, (New York: Columbia University Press, 2005), 39-40. 
to the great animal kingdom and neighbouring with the plant world (the former name for a zoophyte suggests the permeation of these forms), but to a great extent they appear in the form of birds and, most often, mammals because these animals accompany humans most of the time and mean something to them. These are animals with which humans build relationships based on friendship and affirmation of their presence in the human world and also on exploitation and violence. Their anthropomorphisation is not subject to human expression, while species representation turns out to be of secondary importance - this is why they function between the world of humans and nonhumans. It is visible in selected animal narratives by Kafka, Bulgakov, Rilke and Zaniewski. Making an animal the narrator of a story or its fragments, attempting to record its thoughts or present something characteristic to it by referring to the senses that are peculiar to it to a greater extent (e.g. the sense of smell sensitive to stimuli), transferring animal behaviour to activities which require intellectual activities (a dog fond of "digging" in the past ${ }^{31}$ ), hierarchically perceived space (looking up to man) - these are not the only convincing strategies that individualise animals but most they are the ones that are most often applied. Significantly, their individuality and uniqueness may be but does not have to be confirmed by a human hero.

A key feature of animal literary narratives is realistic stylisation, often full of details aimed at recreating as much as possible from the world unknown to people from the inside as they observe it from the outside, that is from the anthropocentric point of view. One example of a detailed description whose role is to make the world seen and experienced by an animal more probable to a human but also to make it impossible for a human recipient to metaphorise it, can be found in Andrzej Zaniewski's Rat. The author has put a lot of effort to get acquainted with these animals which enabled him to present the world which alternately evokes pity, sympathy, disgust and, what is important, the world resisting allegorisation in the context of the human fate, despite the fact that their existence is strongly interlocked with the human one:

This book is both a fact-based description and a tale, a legend so cruel and uncanny, grey and painful like a rat's life and by that it is p r o b a bl e. The community of rodents, living next to us, literally under our feet, has accompanied us throughout centuries, participating in our prosperity and our poverty, in peace and war'32.

31 Franz Kafka, Investigations of a Dog (New York: Schocken Books Inc, 1971), accessed July 2, 2015, http://www.vanderbilt.edu/olli/class-materials/Franz_Kafka.pdf. 
Beginning with all spaces, often co-shared with people but inhabited and colonised by these animals, through events, experiences and expectations fit into the frames of a biographical novel, which sound so realistically that it is hard to read any other meaning to them than the literal one - although there were more attempts at allegorical readings - we are shifted to the rat's real world of murmuring pipes, waterworks, wild animals, abandoned warehouses, holes, traps, whiskers sensitive to touch and warm, female nests. Dangers to which rats are constantly exposed and the unmitigated desire to survive evoke associations with naturalistic literature but are not meant to illustrate human fate through the figure of a rat despite its anthropomorphisation - as it more plausibly happens in Dygasiński's works ${ }^{33}$. Thus, it may be worth asking a question here about the boundaries of even the most realistic animal literariness; on the one hand, about the possibility of confronting their representation with the reality beyond the text which is proposed by the scientific discourse ${ }^{34}$, on the other hand, about the capability of imagining and emphasising by the agency of the text that which happens in the animal world.

In this context, a remarkable example leading the entire group of animal narrators in "serious" literature is Red Peter from Kafka's story A Report to an Academy. The humanised ape, standing in front of the mentioned but absent professors representing a metaphorical tribunal of science, long before the paradigm change in the 1960 s studies on primates, reveals the complexity and ambivalence of the process of its transformation into homo sapiens. Only under the influence of female researchers: Jane Goodall who was occupied with chimpanzees, Dian Dossey with gorillas and Birutë Galdikas with orangutans, and thanks to these women the bias towards these animals was reduced, at least theoretically. They were the first to examine primates in their natural environment without the burden of their usual academic practices, treating animals personally, giving them names, recognising their individual traits of character and discovering the unique personalities of each specimen they were in contact with.

In Kafka's story, Red Peter gives away the origin of his name - it derives from a scar he got at the moment of his capture but it turns out that the name is completely inappropriate and fails to represent his nature ${ }^{35}$. The main

33 Cf. the author's introduction to the novel - Zaniewski, Rat, 7-14.

34 Cf. also the introduction by Susan McHugh to her bookAnimal Stories. Narrating across Species Lines (Minneapolis-London: University of Minnesota Press, 2011), 1-23. Throughout her publication, the author suggests that animal literature builds our knowledge about other species and is the example of "narrative ethology". 
character recounts his horrendous journey from the Gold Coast to Europe which he spent locked in a narrow and dark cage. For the first time in his life he felt that there is no way out which made him realise that he is a wild animal. In order to survive, it was necessary to stop being an ape. The abstract and typically human freedom is deliberately not spoken of - the narrator speaks of "a way out", escape from the captivity. Due to the fact that people on the ship were not - in his understanding - cruel to him, he begins to learn by imitation, just like a human child. This resembles apes' behaviour in contemporary reserves and research centres whose employees know how to gain the trust of animals for didactic purposes: "I did not think things out; but I observed everything quietly. I watched these men go to and fro, always the same faces, the same movements, often it seemed to me there was only the same man"36. Effectively, people seemed uninteresting to him but they were easy to imitate. This fragment, perversely diverting animals' perception of man, may also reflect the lack of perspective which individualises representatives of another species which is characteristic of people's mutual perception of each other - at least in developed Western societies. A breakthrough occurs when Red Peter drinks schnapps and utters a "human" shout owing to which he enters the human community that, as it turns out, has little to offer to a humanised ape: instead of the zoological garden, the main character chooses the variety stage as his final destination.

The story sheds a gloomy light on the period of African colonisation and the practice of bringing exotic animals to Europe. In a way, it gives us much more knowledge about primates than we had almost a hundred years ago when Kafka wrote his bitter report, exhibiting deformation and depravation of the wild animal through its humanisation. The very figure of Red Peter first of all illustrates the cynicism related with his acceptance in human culture: after shows and banquets, there sits waiting for him "a half-trained little chimpanzee" serving to satisfy his physical desires: "By day I cannot bear to see her; for she has the insane look of a bewildered half-broken animal in her eye; no one else sees it, but I do, and I cannot bear it"37. Eukasz Musiał suggests that this text is to be considered "the history of anthropogenesis in a nutshell"38. The human side of Red Peter is born through radical elimination or negation of the animal side, like in Agamben's The Open. Despite the possible philosophical interpretation, the story is bizarre, completely impossible with regard to its ending, however its realistic components - an ape imitating human

\footnotetext{
36 Ibid.

37 Ibid.

38 Łukasz Musiał, „ZwierzoczłekoKafka”, Konteksty 4 (287) (2009), 70.
} 
gestures and performing in the cabaret, self-aware and inclined to introspection - create an equivocal parallel. On the one hand, the same components point to modern research conducted by primatologists and ethologists, especially on primates' intellect, resulting in postulates concerning animals' basic rights such as the right to live, freedom and the prohibition of torture ${ }^{39}$, on the other hand, they remind us that apes are located in zoos, circuses, i.e. in labs serving people's interests, while their natural environment is even worse because to animals which survived till now, almost every man they encounter is a poacher. Red Peter enters the human world as if reflected in a distorting mirror because, in fact, there is no appropriate place in it for these developed mammals which are closest to people. Man either plays with them or tyrannises them - Kafka's character is fully aware of that when looking in the eyes of his half-wild, enslaved partner from the human, studied perspective.

A story similar to that of Red Peter, as it also concerns the transformation of an animal, although it unfolds in different circumstances and is extremely unsuccessful, is told in Bulgakov's tale - until the moment of a true metamorphosis - by a dog living in Moscow, accidentally called Sharik. At the beginning of the story, the character finds himself in a particularly unpleasant situation - he is howling in a gateway having been scalded by a cook from the proletarian canteen. Interestingly enough, Sharik perfectly knows the political reality of the surrounding world and mordantly complains about the "rational" improvements introduced by the equality system:

Dustmen are the lowest form of proletarian life. The dregs of the society, the most inferior category of humanity. Cooks vary - for instance, there was Vlas from Prechistenka, who is dead now. He saved I do not know how many lives of dogs [...] God rest his soul, a gentleman's cook who worked for Count Tolstoy's family and not for your stinking Food Rationing Board ${ }^{40}$.

A man called Philip Philipovich Preobrazhensky (the surname!), an outstandingly elegant and well-mannered professor from the upper classes, takes the dog under his roof. The dog sees it in his eyes that it is an exceptional man who will not hurt him and will feed him: "Eyes mean a lot. Like a barometer. They tell you everything - they tell you who has a heart of stone, who would poke the toe of his boot in your ribs as soon as they look at you - and who is

39 Cf. scientific and ethical premises as well as the criteria conditioning primates to be considered as persons according to "World declaration on great primates", accessed July 4, 2015 , http://www.projetogap.org.br/en/world-declaration-on-great-primates/.

40 Mikhail Bulgakov, The Heart of a Dog, trans. Michael Glenny, accessed June 28, 2015, http:// www.masterandmargarita.eu/archieven/tekstenbulgakov/heartdog.pdf, 2. 
afraid of you"41. The refined scholar decoys Sharik to his home with the help of a sausage and bandages his wound - the dog, as most dogs would do, shows resistance because he does not know what will be done to him:

The dog opened a languid right eye and saw out of its corner that he was tightly bandaged all around his flanks and belly. So those sons of bitches did cut me up, he thought dully, but I must admit they have made a neat job of $i t^{42}$.

It turns out that to his new home, the professor's flat, people come to seek advice on various, most intimate problems. The dog observes patients but also the problems with the proletarian flat committee which his new protector has, claiming that he uses too many rooms of his apartment. Fattened, the dog starts to believe that he is very lucky. For the first time he has walked out in a dog-collar:

The dog trotted along like a prisoner under arrest, burning with shame, but as he walked along Prechistenka Street as far as the church of Christ the Saviour he soon realised exactly what a collar means in life. Mad envy burned in the eyes of every dog he met and at Myortvy Street a shaggy mongrel with a docked tail barked at him that he was a "master's pet" and a "lackey" 43 .

His good fortune ends soon, for he undergoes a bizarre operation. Human organs are transplanted into the dog: the testicles and the pituitary gland. Notes made by the assisting doctor report on the dog's transformation into a man called Sharikov. In his new body, he starts to behave in a vulgar way, he curses and spits, he organises drinking bouts - all this is later justified by the organs coming from a drunkard and a thief but has nothing to do with Sharikthe dog's former life in the streets. It turns out that the pituitary gland eventually affects one's personality. Sharikov cannot be humanised, i.e. civilised and taught good manners. It reminds the professor of the lack of culture presented by Bolsheviks from the flat committee, hence he considers his experiment as unsuccessful and useless. He explains to the investigating officers who want to arrest him for killing a man that science still does not know a good method to transform an animal into a man because he spoke a bit but finally went back

\footnotetext{
41 Ibid., 3.

42 Ibid., 6.

43 Ibid., 15 .
} 
to his original form: before the officers came, the professor decided to give a dog's pituitary gland back to Sharik. The story ends with an image of the dog lying calmly and happily in the scientist's warm and cosy flat, not knowing that his master by no means intends to stop experimenting.

It seems that in Bulgakov's story “the very transformation, described in a quite sketchy manner, is [...] a conventional idea serving the moral and political satire"44. This is why both the dog hero and partially the narrator could be subordinated to this purpose. Sharik, depicted with the use of the realistic convention - full of social details - resembles an ordinary dog but on account of the stream of consciousness technique which presents his life as very fortunate, the rescued mongrel attains - sometimes funny - individual traits and evidently and inimitably blends into the reality of Bolshevik Russia. Fantastic experiments conducted in a private flat, due to their extreme nature, are a separate motif in themselves although it is not neutral in the context of the reflection about the animal being the subject of these experiments. Essentially, the concept of the transformation itself is worthy of our attention. It results in creating a human being with the eponymous dog's heart who, by bearing resemblance to a Bolshevik, proves to be completely undesirable in the noble environment of the Professor. Human intrusion, which turns out to be senseless, reveals that even a trustful and pure heart of a dog is not able to resist it and change into a human without losing its animal, distinct personality portrayed with a great deal of fondness at the beginning of the tale. The realm constitutes a significant background to articulate something important not only by the dog hero but also about himself, on the margin of human matters.

In Kafka's Investigations of a Dog, another dog-narrator, this time a nameless one, speaks about his world from the point of view of a researcher who tries to resolve "dog" mysteries - for instance, where food comes from when it falls down from above - and on this occasion, goes into more complex communication issues. In his argument, people are consciously omitted. The character is different from other dogs and seems to be special among other animals, although he is aware of the conditions of living in a pack. It seems that the boundaries of his world, in accordance with Wittgenstein's Treatise, are marked by the language and ability to communicate with other dogs: "For what is there actually except our own species? To whom beside this species can one appeal in the wide and empty world? All knowledge, the totality of all questions and all answers, is contained in the dog"45. He is interested in

44 Janina Abramowska, Pisarze w zwierzyńcu (Poznań: Wydawnictwo Poznańskie, 2010), 100 [translation mine]. 
the dog's nature, culturally perceived as submissive and mute, but the more he thinks about it, the more acutely does he discover his loneliness and the more difficult it is for him to initiate contact with another specimen: "he gazes at me dully, wondering why I am silent and why I have broken off the conversation. But perhaps that very glance is his way of questioning me, and I disappoint him just as he disappoints me" 46 . These doubts, concerning any verbal and non-verbal communication whatsoever, show difficulties in building a relationship. A dog may be just as well lonely because, in the end, he is a social animal, even if we do not have sufficient knowledge on how he de facto communicates with other members of his pack. In Kafka's Investigations of a Dog, the author tries to prove that in the non-human world, an animal may be a conscious centre of thoughts and feelings, a remarkably isolated individual in spite of belonging to a species characterised by living in groups. In the story told by the dog, there are also attempts to include in the narrative the senses that are typically keen for his species: smell, hearing and touch. The final confession of the main character - that he appreciates freedom - is aimed at emphasising his autonomy which he misses so much not only in his "dog" world but also in the human one.

Musiał notices that even human characters in Kafka's stories are not completely human as they are prone to all types of corporeal degeneration ${ }^{47}$. They feel guilty and have dilemmas in view of the dark depths of the body, obscure affects. In other words, what resonates here is nonhuman because it is strange and unfamiliar to a human being. That is one of the ways to explain the multitude of Kafka's animal and hybrid characters. What is striking, however, is why all animals described above - Zaniewski's rat, Bulgakov's Sharik or Kafka's ape and dog - depicted by means of an inherently realistic convention and unpupated, seem to represent, convincingly and earnestly, the animal world which is probably to a lesser or greater extent hidden by the veil of human ignorance.

We find a similar problem in Kafka's short story entitled The Burrow ${ }^{48}$ where the narrative is developed by an animal unknown to the taxonomy of species. What we know about it is that it digs itself into the ground, ceaselessly guards its shelter, and is vigilant and skittish. Due to its naturalism, the story resembles Zaniewski's Rat which differs from the hitherto promoted pattern of the story about man. In its reading, preceded by the posthumanist critique

46 Kafka, Investigations of a Dog, 332.

47 Musiał,ZwierzoczłekoKafka, 72.

48 Franz Kafka, The Burrow (New York: Schocken Books Inc, 1971), accessed July 2, 2015, http:// www.vanderbilt.edu/olli/class-materials/Franz_Kafka.pdf. 
of anthropocentrism and the related approach restricting the discriminating power of the language, at least with regard to the species affinity of the hero, both animal characters may say something "from the heart" about their feeling of no right to a piece of land, the desire to live in a safe place which they are deprived of, being constantly menaced by other predators including the most dangerous of them all: man. Their narration either contradicts stereotypes associated by people with a given species, as in the case of The Rat, or the species stops being a significant point of reference, like in The Burrow where it gets blurred and consequently, retrieves the content from the rule of the senses. Kafka's "burrow" and rat's den, idyllically co-shared with the first and most important family, are testimony of the crucial role of place and shelter in the narratives of anthropomorphised animals but also reflect general needs of other sentient creatures which man can emphasise and which man can imagine through the language of literary transmission.

\section{The Animal Closer than the Angel}

Human narratives about animals, even these closest to them, such as the biography of the cocker spaniel Flush proudly described by Virginia Woolf or a detailed observation of the pointer Bashan in Thomas Mann's story A Man and His Dog, rather confirm the current hierarchical world in which animals, despite being admired and loved, are eventually subordinate to people. This is why it is worth to mention A Meeting (Eine Begegnung) - Rilke's short sketch in which "the dog all at once appears, like a sudden thought"49, closer than an angel because it is real, material and persistently accompanying any man he accidentally comes across.

This narration, quite surprising by its short form, tells a great deal about relations between people and animals on the basis of the example of dogs living in their proximity. As presented by Rilke, even though the animal is busy with its "lower" activities, it keeps accompanying any passer-by selflessly and without a specific reason, according to its nature. It would seem that it a quite typical situation showing the man and the dog as simplified character types who pursue - albeit for different reasons - reciprocity which looks like a philosophical parable.

The text underlines the dog's emotions and enthusiasm with exclamation marks thanks to which man is distinguished as well. At some point, the dog

49 Rainer Maria Rilke, A Meeting in Ahead of All Parting: The Selected Poetry and Prose of Rainer Maria Rilke, trans. Stephen Mitchell (New York: The Modern Library, 1995), accessed on July 10 , 2015, http://www.penguinrandomhouse.com/books/154354/ahead-of-all-parting-by-rainermaria-rilke/, 283. 
manages to stop a passer-by: "The excitement in the dog's eyes changes into embarrassment, doubt, alarm. If the man does not know what should come, how can it come? - Both of them have to know; only then will it come"50. The dog tries to look this man in the eyes. Their meeting is cast in the style of a conversation carried on in their minds. They confront, their eyes are fixed on each other which makes the dog begin to fawn, completely subordinated: "I'd like to do something for you. I'd like to do anything for you. Anything"51. In spite of the man's reluctance, the animal does not give up, wishing to endear himself to the man using all his creativity (not able to find anything valuable, he picks up a stone in his mouth). At the same time, the man inconclusively appeals to the dog's reason asking him to stop, even though the dog is overcome with emotions: devotion and the need of reciprocity. The man turns to him as to a partner but the dog: "is accompanying him, unobtrusively, devotedly, without an opinion of his own, the way a dog follows his master"52. The man realises that he would like to treat the dog as someone equal to him, rejecting the animal's natural proneness to submission. He asks the dog to go away and in order to make sure that he leaves him behind, he starts to run because that is the only way - urgent and surely obnoxious - to get rid of it. Eventually, however, when the dog is gone, he realises that he would be keen to talk with the animal as he would do with an unknown person - out of the "indescribable" yearning for a radically strange person but who might turn out to be close. This unconfirmed presentiment probably stemmed from the human character's loneliness. In such moments, animals often appear to be the closest friends, most devoted to us regardless of what we think about them. Similarly, anthropomorphisation may paradoxically unveil a conviction that we do not know much about them, so we confer human traits on them. Still, this closeness makes us anthropomorphise them because it seems to us that we know and understand what they feel ${ }^{53}$. Every time we take a certain risk, as in A Meeting's ending, when "there is no one to be seen", the dog or any other nonhuman animal.

50 Rilke, AMeeting, 283

51 Ibid., 284 .

52 Ibid., $286 .$.

53 There is interesting related research on guardians of animals, particularly dogs and cats, who perceive animals as conscious and reasonable creatures that people can talk to and they understand; these people can also verbalise what animals under their custody feel - cf. Clinton R. Sanders, Arnold Arluke, Speaking for dogs in: The animals reader. The essential classic and contemporary writings, ed. Linda Kalof, Amy Fitzgerald, 61-71. 


\section{Conclusion}

Animal characters' narratives enforce a reflection upon several new matters, especially in the context of Wolfe's thought. A question is posed: what about the rejected human subject in whose speech even earlier one could hear an echo - so natural, albeit drowned out - of what is nonhuman, animal-like? Is it not so that human subjectivity, even in a weak sense, serves here as an instrument, a mediatory agent in conveying messages from other creatures, since their voice is uttered in other languages? Then the above-mentioned texts of animal narratives would function as a translation, an attempt to demonstrate the possible capacity of literary subjectivity which is not at all equal to the human one only but, in its essence, is posthuman or not only human ${ }^{\mathbf{5 4}}$. Hence, entering the field of a literary text which necessarily affirms the nonhuman, always using tools ex te $\mathrm{r}$ al to man and other animals such as the constructed language, we open up to possible mediation in literature but also in a broader context - in the language of art - to other points of view. Despite the technological nature of the language and the feeling of its alienation, animal narratives may be an example of familiarising these strange elements within which we function and which - by means of another stylised voice give the possibility to go beyond the narrowly defined world of selfish human kind.

Summarising critical tendencies characteristic of posthumanism, Ewa Domańska wrote that nowadays, a "narcissistic" human subject is subject to criticism and the human community and collectives are increasingly spoken of as they are associations of humans and nonhumans but also a popular view is that man is a guest in this world, not its master ${ }^{55}$. The same situation applies to a text or any other product of culture which involves an animal narrative in the form of a nonhuman perspective. These texts are special for their hospitability - a nonhuman story representing realistically depicted animals contains a model of non-domination of man over text. Giving voice to animal characters brings the sense of environmentally oriented posthumanities because it is aimed at reconstructing heterogeneous relations in the world which we also share with other species, therefore it raises an issue of the boundaries and limitations of emphatic sensitivity but also makes it real to get closer to the world of nature from which we moved away so much, endangering the survival of both human and nonhuman ecosystems.

54 Wolfe, What is Posthumanism?, 122.

55 Ewa Domańska, „Jakiej metodologii potrzebuje współczesna humanistyka”, Teksty Drugie 1-2 (2010). 
Jarosław Płuciennik wrote about "cognitive empathy", i.e. "representation of the observed subject's state", about "taking over the subject's perspective" 56 and illustrated it with Szymborska's poem The Cat in an Empty Apartment. In his opinion, in works featuring animal characters - and this also concerns the ones discussed in this text - the narration is produced by an observer who empathises with an animal but it also becomes a personal narrative created from the point of view of the nonhuman animal itself. In this aspect, human and animal experiences intersect, while the reader gets involved and faces the speaking subject regardless of its species identification. What is left in the end is the human community of diverse viewpoints supported by empathy as a keystone. What is important in the present article is to use the posthumanist reflection to go beyond the community constantly defined as human and to show possible overlaps with non-human Others, realistically depicted animals which represent themselves in the text and which are a relevant contribution to criticism of the humanities centralised around the category of the ruling human subject. Animal narrators may be subjects of creating knowledge and new channels of conveying meanings and, as new characters, they impose a reflection upon human attitudes towards them. Their characteristic literary voices can be perceived - after Wolfe - to have a special role in establishing a diagnosis of the condition of disciplines aiming at refuting the anthropocentric approach. Will we ever be able to hear their real voice, not mediated by anthropomorphisation, which literature tries to imitate?

Translation: Marta Skotnicka

56 Jarosław Płuciennik, Literackie i językowe punkty widzenia a empatyczne naśladowanie $w$ tekście literackim in: Punkt widzenia w tekście i dyskursie, ed. Jerzy Bartmiński, Stanisława Niebrzegowska-Bartmińska, Ryszard Nycz (Lublin: UMCS, 2004), 204. 